\title{
A Child Language Acquisition in Indonesian and English Language: A Longitudinal Case Study
}

\author{
Somariah Fitriani \\ University of Muhammadiyah Prof. DR. HAMKA, Jakarta, Indonesia \\ somariah@uhamka.ac.id \\ DOI: https://doi.org/10.18326/rgt.v12i2.126-156
}

\section{Submission Track:}

Received: 12-02-2019

Final Revision: 20-11-2019

Available online: 01-12-2019

\begin{abstract}
Learning a dual language at the same time during early childhood has caused the wrong perception. Its false perception makes the parents delay the start of learning a second/foreign language. Therefore, this study aims at analyzing the first and second language acquisition of a child in the Indonesian Language and English. The issues concentrated on the spoken utterances in Indonesian and English and its affecting factors. The research adopted a qualitative approach by using a case study, as the unit analysis is a child of 3 years old. For data collection, I employed the naturalistic approach, which I kept daily notes on the progress of a child's linguistic and recorded the dialogues. Since it is a longitudinal study, the research was conducted for two years, from 2014 to 2015. The research has revealed that utterances spoken have primarily increased and the child has already understood the commands by following the instructions. Some concepts such as feeling, taste, color, and numbers as well as short phrases and simple words in Indonesian and English at the same time can be understood and uttered. She also can change the
\end{abstract}


affirmative sentence to question in term of objects she sees in her surroundings. Factors such as linguistic input, imitation, environment, exposure, and language acquisition device can all affect the child's utterance. Thus, it indicates that two languages can be taught at the same time at an early age, and it doesn't cause misunderstanding or confusion.

Keywords: utterance, language acquisition, exposure, L1 and L2.

\section{INTRODUCTION}

Research about language acquisition and its development, particularly to certain ages of children is always thought provoking to conduct. Some previous researchers conducted research on children language acquisition and its development including Brown (1973), Fletcher (1985) and Halliday (1975), Dye, C., Kedar, Y., \& Lust, B., 2018), Pernille (2017) and research on developmental sequences and the process of acquisition including Ellis (1994), Lightbown and Spada (2006). The central questions of language acquisition and its development relate to why and how a child succeeds in acquiring language. One of the issues of a child language acquisition is some parents' wrong perception about delaying learning a second or foreign language to their children at the same time (Genesee, 2008). Some common beliefs and myths are that the children will be at high risk for academic failure if they learn two languages at the same time (Espinosa, 2008). They believe that learning two languages is a burden and puts children at risk for delayed, incomplete, and possibly even impaired language development, not to mention cultural and social anomie. Likewise, parents are mostly worried that dual language learning may result in confusion to their children or known as language confusion myth (Cummins, 1981; Harry, 1992). 
Some studies have found the advantages of learning two languages in early childhood to responding to the parents' skepticism. Bialystok and Martin (2004) and Genesee and Gandara (1999) found that the children are better at problem solving, demonstrate greater creativity and express more tolerant attitudes. Genesee, Boivin, \& Nicoladis (1996) said that research has shown that even toddlers in the early verbal stages of simultaneous bilingual development know how to use their languages separately, even with strangers they have never met before. The study also revealed that bilingual children have equal or more productive vocabulary skills than monolingual children (Ferjan Ramirez, Ramírez, Clarke, Taulu, and Kuhl, 2016; Hoff, et al, 2012). Genesee, Boivin, and Nicoladis (1996) acknowledged that research has shown that even children in the early verbal stages of simultaneous bilingual development know how to use their languages separately, even with unfamiliar person they have never met beforehand. Correspondingly, the graph of a simplified schematic of second language learning shows that despite adults' cognitive superiority, infants and young children are genius and superior learners compared to adults (Kuhl, 2011). Under this circumstance, I attempted to investigate and analyze a female child's language acquisition of Indonesian and English since she was a baby. However, the research focuses on the linguistic development of Indonesian and English language at the age of three years to four years old and the factors affecting the child utterances in Indonesian and English language.

The term of language acquisition is often used to refer to the learning of language structures or rules, especially those of grammar, phonology and soon, whereas, the term of development usually refers to the child's use of the 
acquired language rules and structures in a widening variety of language contexts (Wray and Bloomer, 2006). Nordquist (2018) acknowledged that language acquisition refers to the language development in children and second language acquisition (also known as second language learning or sequential language acquisition) speak of the process by which an individual learns a "foreign" language - that is, a language other than his or her mother tongue. Krashen (1995) added that acquisition is the subconscious assimilation of the language without any awareness of knowing rules. He also emphasized that acquisition is the unconscious process that occurs when an individual uses language in real conversation and ordinary conversation (Krashen, 2003).

Brown (2007), Johnson (2004), and Heidar (2012) summarized theories on the language nature, which indirectly indicate how a language (L1 \& L2) is acquired. The behavioral approach postulates that language is acquired behavior through conditioning and reinforcement. The behaviorists believe in nurture that the child's mind at birth is like a blank state (Hoff, 2001). Based on this approach, a child learns language from the conditioning and reinforcement of the environment involving family members, teachers, peers, and society as a whole. As "good imitators," children imitate what they hear and see, and what people say and act in their surroundings. Fromkin, Rodman, and Hyams (2003) highlighted that imitation plays a role to some extent. Brown (2000) also pinpoints that language learning is the result of imitation, practice, feedback on success, and habit formation. Also, Goldstein (1984) reported that corrected practices enhance language learning, whereas, unlike the behaviorists, cognitivist theory of Chomsky (1965) cognitivist theory posits that language is predominantly cognitive, mental process and rule-governed (universal grammar) in deep and surface structures (Brown, 2007; Green \& 
Piel, 2016; Heidar, 2012; Orillos, 1998; and Tahriri, 2013). Chomsky reported that linguists have proposed that a child's brain contains a 'language acquisition device,' which embodies rules of universal grammar. Because each language expresses these rules in slightly different ways, the child must learn the details, given that but the basics are already in the brain (as cited in Carlson and Buskist, 1997). Chomsky also contended that the child is born with an innate knowledge of or the predisposition toward language and that this innate device (the LAD or UG, universal grammar) is universal in all human beings (cited in Brown, 1994). It means a language acquisition device is not a "device" like a tool inserted in the brain, but it is the human's brain where languages are acquired.

Studies on children's language acquisition have received sufficient attention to linguistics discipline up to now, especially, research on how children acquire and learn English as a second or foreign language. For example, Mushi (2010) researched parents' role in their children's English language development, in which they are from immigrant families. The study revealed that the role of parents supported the children's language learning. Lin, Cheng \& Wang (2018) examined the contribution of cross-language phonological and morphological awareness of reading acquisition in bilingual children. Tong, McBride, Ho, et al. (2018) investigated the effect of morphological awareness to students who learn Chinese, and English. In Korean students' experiences, Lee \& Jeong (2013) examined the KoreanEnglish dual language immersion program to develop bilingualism. It can be inferred that research about children's acquisition on both L1 and L2 is still interesting to analyze in different countries. In the Indonesian context, a similar 
study was conducted on the acquisition of Indonesian as first language and English as a foreign language. This study emphasized on a three-year female child of language acquisition and her development of two languages Indonesian and English. Therefore, the research questions are as follows:

1. What are the spoken utterances of a child in Indonesian and English language at the same time?

2. What factors affect her utterances?

\section{RESEARCH METHOD}

\section{Research design}

The study was to describe how a three-year-old child acquires and learns two languages, Indonesian (L1) and English (L2) almost at the same time and its factors affecting her language acquisition. Since the study intended to collect the data in the form of words and sentences rather than numbers for around two years. The research employed a qualitative approach by using a case study method. Yin (2003) highlighted this case is essential, unique, typical, revelatory and longitudinal. Yin (2003) also added that a case study is an empirical inquiry investigating a contemporary phenomenon within its reallife context. Additionally, a case study is "an in-depth study of specific circumstances used to reduce a vast field of research into one easily researchable topic" (Shuttleworth, 2008).

\section{Respondent of the study}

The unit analysis is a person - a child named Addien as a respondent. She was a three-year-old when I started conducting the research. She is the first child of two other twin siblings. She was a kind of shy girl who didn't want to communicate with others if she didn't recognize them. However, when she was 
at home, she changed to be a cheerful girl who loved dancing and singing. Besides, she was remarkably good at posing in front of the camera. Without any doubt, every time I took pictures of her, she directly posed with many kinds of styles. She is a girl who enjoys observing people's speaking, particularly in English. For example, every time she heard a word in English from me, she could repeat it in another day in a proper way, even though I did not teach and say the meaning of the word. On account of living with her parents, uncles, aunties, nieces, nephew and me (who often speaks English with her), she is exposed to two languages; Indonesian as first and dominant language and English as a foreign or additional language. Occasionally, some others talk to English too, such as her mother, and her auntie. But she dominantly heard English from me.

\section{Data procedure and analysis}

It took me about two years from 2014 to 2015 to investigate, record, and analyze the data from the child. For data collection, I adopted the naturalistic observation which in the naturalistic approach, investigators observe and record children's spontaneous utterances. One type of naturalistic investigation is the so-called diary study, in which a researcher (often a parent) keeps daily notes on the progress of a child's linguistic competence as stated by Denzin and Lincoln cited in Cresswell (2007). To analyze the data, I used Miles and Hubberman's (2014) model, which consists of data reduction, data display, and conclusion and drawing/verification based on existed theory. I also analyzed the notes through the content analysis technique. While for the credibility of data, I used triangulation to make sure that the information and its interpretation have already been in the right one. I used two kinds of 
triangulation; 1) source data triangulation by people surrounding the respondent, such as her parents, her aunties and her uncles; in this triangulation, the researcher did cross-check the information; and 2) method triangulation by observation, interview and document analysis of her writing.

\section{RESULTS \&DISCUSSION}

\section{The spoken utterances at the age of three to four years}

At the age of two years old, she was taught to call her mother Ami and her father is Papa. However, she found it difficult to call me Mami. So she called me Mimi. She also found it difficult to utter Tante Uki, my younger sister, so instead of $U k i$, she uttered $u i$. She also couldn't say Tante Asih, my other younger sister but later after around three years old she could say te Aci and te Uki, but later in the next few months, she could utter Tante. She could not utter her name properly by Addien. She called herself "tata Endin" instead of Kakak Endin, since she couldn't pronounce consonant $k$. But she can recognize the letter A, indicated her name. So every time there is a word with a letter A, she must say "Addin" with long $A$-and emphasized the sound stress of din with AAAddin.

At the beginning of three years old, she always asked questions such as Apa ini? (What is this?), Apa itu? (What is that?) Then she started asking ada apa? (What happens?), siapa? (Who). Here is one of the example conversations between her and me. She quite often mixed up between ini (this) and itu (that). She just said what she saw in her surroundings and jumped from one topic to another. When we were in the restroom, I used English to request her to do something such as stand up, sit down; stay there and amazingly she understood the command and did what I asked her to do. I also sometimes sang 
a song like "wash your hand, wash your face, wash your hair and wash your lip and mouth, wash your body, your legs, and your feet (while touching her part of the body) to be healthy, to be fresh, to be beautiful". To make it easy, I use a letter $\mathrm{R}$ as my name, a researcher and $\mathrm{A}$ as Addien to show the dialog or conversation.

R: Stand up

A: (follow my instruction)

R: Sit down

A: (follow my instruction)

R: brush your teeth

A: (she took toothbrush from hands and brushed her teeth)

R: Do you want to use this? (Point to the soap)

A: Apa? (What?)

$\mathrm{R}$ : Merem, close your eyes

A: (follow my instruction) (DATA 1)

Remarkably, I never used the word "merem" to her but she could do it. She might get it from someone else. She could also tell the story to her mom with uncompleted sentences, especially after returning from shopping or going out somewhere with me. Here is the dialog between Addien and her mother (M).

M: Kakak Addien dari mana? (Where have you been?)

A: lihat balon (seeing balloon)

M: ada berapa balonnya? (How many balloons are there?)

A: banyak sekali (a lot, while raising her both hands up and making the circle)

M: ngapain lagi? (What else?)

A: banyak anak anak. Main, mam ayam ice cream (A lot of children, play, eat chicken, ice cream)

M: senang nggak? (Are you happy?)

A: ya

M: mau kesana lagi (Do you want to go there again?) 


\section{A: Маииии (with long u) (I want) (DATA 2)}

Since she started to produce some words, there are some words that she never wanted to change even the family corrected again and again. For example, the word yeye means gendong (carry on the back or hip). Every time she wanted me to carry her, she always said yeye. Other words are mam means makan (eat) abab means Allahuakbar indicating to take prayer. Mimi Iyah mau abab ya? (When I was about to take a prayer), nen means asking for milk, momon means Dora Emon (Japanese character), рири рири means Кири kири (butterfly).

After dressing up, she wanted to go outside and I gave the wrong sandal to her and she said: Salah (it's wrong), Mimi Iyah. And then she saw a bike falling and said "jatuh sepedanya." She saw fish food and said "ini mam ikan" (Should be itu), "kakak kasih Ikan mam." Other example dialogue is shown in another day when she wanted to eat rambutan.
A: Mimi Iyah, ada rambutan (point to rambutan)
$\mathrm{R}$ : (I gave rambutan to her)
A; Kakak Endin mam rambutan (while eating rambutan)
$\mathrm{R}$ : ini punya siapa? (Whose rambutan is this?)
A: kakak Endin
A: ini nggak enak (not delicious while pointing to Duku)
A: mau pipis (I want to pee) (DATA 3)

After playing a game on I Pad with her cousin, Zein, she saw a sign of battery and said:

A: " ini udah abis, cas (Charge) dulu" (it's out of battery, needs to be charged)

A: "ini kotor, Zen no! (This is dirty)

A: "kakak Endin udah naik kereta api"'(Kakak Endin took the train)

A: “abang Zein belum naik kereta api (Abang Zein hasn't taken train yet) 


\section{A: “abang Zein, no! (DATA 4)}

One day after our dialogue she saw a butterfly and said "itu sayap" (that's wing) but she tried to think first, it seemed that she tried to recall her memory before producing the word "itu sayap." She has also already expressed her opinion and her feeling about taste. When I gave her a black bucket to soak her body in the bathroom, she asked me a red one and said: "jelek" (ugly) pointing to a black bucket.

She can give me praise too by saying "Mimi Iyah yang cantik." (Mimi Iyah is beautiful). When I asked my sister, she often said "Kakak Addin yang cantik" One day in the evening when I was watching television, she carried her teddy bear doll and said with a sad face, knowing the word "mati", (dead) that surprised me.

A: "papa Abu mati Mimi Iyah" (Papa Abu is dead. She called her teddy bear with papa Abu even though the color is brown)

R: tidak mati, Papa Abu bobo (no dead, but sleeping)

A: oh bobo

$\mathrm{R}$ : iya, disayang ya (well, love him)

A: (hug the teddy bear) (DATA 5)

She often shows her high curiosity as well by asking a question, for instance when I got a phone call by saying "siapa Mimi Iyah." (Who is it?) When I talked to someone in my graduation day, she said " ada apa Mimi Iyah." (What happens?). When I got angry with my nephew and she heard my voice from the room, she was in a rush going out said too " ada apa Mimi Iyah." Sometimes I explained to her, but sometimes I just said "nggak ada apa apa." (Nothing happens). When I explained, she pretended to understand and 
said "oh." Even to her aunty, every time her aunty returns from work, she always asks what her aunty brings to her.

A: anti Asih bawa apa? (What do you bring?)

Aunty: bawa roti (I bring bread)

A: roti apa? (What bread?)

Aunty: roti coklat (Chocolate bread)

A: kakak Adin suka coklat. (I love Chocolate bread) (DATA 6)

Every time she finishes her activity, she quite often reports what she has just been doing and pretending to do something like below dialogue.

A: Mimi Iyah, kakak Endin udah makan (I have eaten). (I am in front of laptop

typing)

R: Kok cepat banget (so quickly)

A: Silent (it seems she doesn't know to how to answer)

R: Makan apa? (What do you eat?)

A: Telor cepok (sunny side up eggs)

A: Kakak Endin mau photo booth (I want to take picture using photo booth, application in I Pad)

A: Entar dulu ya Mimi Iyah mau kerja. (Wait a minute, I want to work) $\mathrm{R}$ : (silent)

A: Adek mau bando nggak (Do you want bandana? showing a cartoon bandana to Maryam, her cousin who is still a baby of 6 months old).

A: Mimi Iyah, Endin mau photo booth, itu ada tuh photo booth nya (A few times said the same thing)

$\mathrm{R}$ : Sebentar ya, just a minute

A: a few minutes later

A: Mimi Iyah, Adik kembar bobo (Twin sisters are sleeping)

A: Mimi Iyah mau photo booth (DATA 7)

Finally, I let her sit in front of my laptop and she started to play a photo booth, after about 2 minutes she got bored and I started to type again.

A: es cream, es cream (she shouted ice cream and played with Zein while holding a drumstick) 
A: Mimi Iyah, ambil es cream (Please take ice cream, she pointed a drum stick in front of me)

$\mathrm{R}$ : ini bukan es cream (this is not ice cream)

A: pura puranya es cream. (Pretend to be ice cream; I was amazed by how she can say such a thing)

A: es cream es cream (she was shouting and laughing together with Zein) A few minutes she saw Zein sitting on her younger sister, Maryam)

A: Mimi Iyah, Adikknya ditindihin. (Zein is sitting on Maryam)

A: diam nggak, nanti nggak diajak ke Tip top (Please be quiet, I won't take you to Tip Top supermarket while talking to zein)

A: Kakak Addien marah nih.( I am angry, She often says this thing to Zein with protruding eyes, and loud voice) (DATA 8)

She often says "mana ya Mimi Iyah" (Where is Mimi Iyah) while closing her eyes and wandering to look for me. Her mother often plays this game to her. And she does it to me too. From some examples of the above dialogues, it can be inferred that at the age of three to four year, she can produce a complete sentence with some correct grammatical structure and able to create many consonants correctly with all vocal sounds. She can also develop the questions by using ini apa? (What is this), become ada apa? (What's up), and siapa? (Who is it?). Surprisingly, she could also change it's a towel with is it a towel? And point to other things by saying is it a towel? I said no, it is a tap, it is a tub, etc.

At the age of three, Addien has already understood some concepts, either in Indonesian or English since her mother and I use English when communicating with her so that she can use Indonesia and English at the same time.

1. The concept of part of the body: 
She understands when I say "which one is your nose, eye, ear, hair?" she can point her part of the body but she can speak only nose, ear and eye. Her mother has introduced her some part of the body particularly around her face since she was about two years old and reinforced by me especially when she takes a bath, such as a nose, eye, hair, and lips.

2. The concept of numbers: 1 -10 in English and Indonesian.

She can follow and repeat what I say about the number in Indonesian and English. She memorizes number 1 to 5 either in Indonesian or English at first but later on, she can say until 10. She also knows the number of things, for example, two things or 4 things. Her mother put pictures of animals, transportation, numbers, and fruits on the walls to make her accustomed to seeing the objects.

3. The concept of feeling and taste.

She knows and understands the feeling of sadness, and happiness and taste of food, sakit (sick), gatel (itchy), capek (tired), tidak enak (not delicious), pedas (spicy), bau (smell bad) and wangi (fragrant) (especially after using perfume or taking bath)

4. The concept of colors

The name of the color that she knows firstly is in English, that's why every time we ask what color is, she can answer red, merah, pink, but when saying blue, he says lue or, biru. It seems she understands that red is merah, blue is biru. But until almost four years old, she finds it difficult to pronounce purple. So the colors she knows until now are blue, pink, purple, red, green, brown and white.

5. The concept of animals 
The first time she utters fish with ипуи ипуи but later after we said that it is fish, she changes it. But once after almost a year she never said unyu unyu as a fish, one day she said that again. She knows some animals and able to differentiate in English like fish, dog, cat, and horse. In Bahasa Indonesia, she knows cicak (lizard), kucing (Cat), Gajah (Elephant), capung (dragonfly),tikus (Mouse), semut (Ant).

6. The concept of objects

The first object she introduces is an umbrella, that's why every time she sees an umbrella; she must say "umbela." Since she always sees me making up, she knows some cosmetic terms such as lipstick, eye shadow, bedak, (powder) shampoo, sabun (soap). Other things are piring (plate), gelas (glass), sendok (spoon), botol (bottle), hand phone, remote control, laptop, IPad, tas (bag). She also can differentiate between hand phone and iPhone, between tablet and IPad.

7. The concepts of fruits

Some fruits that she can utter and recognize are rambutan, pisang (banana), manga, papaya, melon, $d u k u$, jeruk (orange) since those fruits are consumed regularly. She loves rambutan and banana very much.

8. The concepts of transport

She is familiar with some transport both in English and Indonesian such as mobil, car, sepeda, pesawat, bis, bajay, odong odong, kereta api, train.

Even she cannot respond or reply to my questions in English, and it seems she understands the meaning, like the below dialogue.

R: Put this bottle in the kitchen and wash it ok 

A: No
R: Sudah ketemu adik kembar (have you met twin sisters) and kiss?
A: No
R: Take it (a bottle on the floor) and put it on the table
A: (she took it and put it on the table) (DATA 9)

I was in the bedroom doing my work, when she was crying and saying "Mimi Iyah" (the previous night, she slept in her mother's bedroom), and I opened the door seeing her going back to her room.

$\mathrm{R}$ : ada apa kakak Addien? (What happen?)

A: (she was still crying)

R: (I held her hand to go to my bedroom)

R: Kakak mau ikut ke kampus? (Do you want to come with me to campus?)

A: (nod her head)

$\mathrm{R}$ : ok drink your milk and sleep first

A: (she lied her body on the bed while drinking a bottle of chocolate milk)

R: (I continued typing)

A: mau mandi (I want to bathe)

R: sebentar ya, Mimi Iyah lagi nonton. (Wait a minute, I am watching)

A few minutes later after the movie ended

A: Mimi Iyah, mobil sudah dibetulin ama papa. (Car is already fixed by Papa)

R: (I just nodded my head and took her to the bathroom)

A: Kakak Addien mau pakai sabun ini, sabun orang gede (I want to use this soap, adult's soap)

R: (I was washing clothes)

A: Mimi iyah pinter ya, Kakak Addien juga pinter (You are smart, I am smart too. She took her panty and washed it)

A: Kakak Addien mau abab (means "sholat" take prayer)

(She followed my acts taking "wudhu.")

$\mathrm{R}$ : ok stay there (after finishing her bath, I took a towel in a bedroom)

A: (follow my instruction)

A; handuk baru ya! (New towel isn't it?) 
R: ya (I took her to my bedroom), Mimi Iyah sholat dulu ya (I want to pray first)

A: ya

R: kakak mau nonton Barbie? (I want to watch Barbie)

A: ya, itu kakak Addien udah punya, bisa terbang (I have Barbie's movie, she can fly)

(Barbie movie: a super girl who can fly) (DATA 10)

One day when she was playing and asking me to help her pretend she was almost falling and she shouted "hep" means "help" since I said "help" a few times to her and pretended to nearly falling. It seems that she saw what I was doing and repeated it the action.

When she was about to go outside and asked Abang Zein to come with her, she said: "come on bang Zein." And every time I asked her to kiss her twin sister, she directly kissed them or sometimes she said "no." So far there are more than 20 English words she can utter and produce from the simple ones of one word such as, "ok," "yes," "no" "kiss" until two words such as come on, take it, let's go. She could produce a long sentence too, for instance, when we went out to the pool after jogging, she could say a long sentence. "Wow, it's so beautiful, oh my God, come on Abang. Let's go. Take a picture".

Based on the above data, it can be concluded that a child of three to four years old can utter and produce the second language in the early childhood and she has some extent a good understanding of the meaning of the English words as well. Thus, the use of two languages at the same time can be learned without getting confused to differ the two languages. Lightbown (2008) summarized that the children in early childhood have capability of acquiring two or more languages. Genesee (2008) pointed out that no scientific reason to 
believe that the brains of young infants are equipped to learn only one language in early childhood. Genesee (2002) and Lightbown (2008) also revealed that there is no evidence that children get confused if they learn two languages during the infant-toddler period. Hyltenstam and Abrahamsson (2003) even emphasized the importance of rich learning environment to become fully bilingual children. In this context, the researcher uses two languages in the same sentence, which is referred to as code mixing or code switching to ensure her understanding, especially if she seems unsure about the meaning of the word.

\section{The factors affecting her utterances}

\section{Linguistic Input}

The role of input affects a child's language development. Children, who do not receive input or exposure to a language, will not develop their linguistic ability normally. This linguistic input is called "positive evidence" as a part of the language aspect discussed by Pinker (1995), which refers to the information available to the child, about which strings of words are grammatical sentences of the target language. Fromkin, Robert and Hyams (2003) contended "Children who do not receive linguistic input during their formative years do not achieve native-like grammatical competence." Lenneberg (1967) called the formative years as a critical age hypothesis that is a part of the biological basis of language that the ability to learn a native language develops within a fixed a period, from birth to puberty. During this critical period, language acquisition proceeds easily, swiftly, and without external intervention (Fromkin, Robert and Hyams, 2003). However, variation in input quantity (i.e., the amount of language children hear) significantly affects children's acquisition (Weisleder and Fernald, 2013). In addition, variation in input 
quality plays a role as well. Some important indicators of quality include the use of decontextualized language, lexical diversity and properties of verbal and nonverbal interaction (Hirsh-Pasek, et al., 2015; Rowe, 2012; Rowe, et al, 2016)

In the case of Addien, since she lives with a lot of immediate families (there are eight adults altogether) and gets a lot of exposure either in Indonesian and English (mostly from the researcher), her linguistic ability develops a lot. Her utterances are like most normal children who start producing one word, two words and more complete sentences consisting subject, verb, and noun or adverb either in affirmative sentences or questions. She can understand what people say and act, utter the words, produce the sentences, and respond to people in her surrounding, even to the activities she watches on television. For example, when she saw a man running on TV, she said "hati hati nanti jatuh", (be careful or you will fall down). She also remembers and recognizes all of the things belong to us. "Ini punya Ami or ini punya Mimi Iyah, (This belongs to Ami or This belong to Mimi Iyah) or when I wore my sister's veil, she said "ini punya tante Uki." She can as well as express her own opinions when I ask what color she wants or the kind of clothes she likes; what food she wants to eat, and soon. Therefore, this critical period has a great impact on a child language development. After this period, the grammar acquisition is difficult and for some individuals it is never fully achieved. Like a case of Amala and Kamala who were found in India, a case of Victor who was found in 1798 or Genie who had been confined to a small room under the conditions of physical restraint and had received only minimal contact from the age of eighteen months until almost fourteen years. Regardless of the cause of isolation, none 
of these children could speak or knew any language at the time of reintroduction to society. In can be inferred that their linguistic inability could be because they did not receive linguistic input, showing that exposure to language must trigger the innate neurological ability of the human brain to acquire language (Fromkin, Robert and Hyams, 2003). However, no one is sure how long the critical period lasts whether it will decline or increase throughout adulthood (Hartshornea, Tenenbauma, and Pinker, 2018)

\section{Language Acquisition Device (LAD)}

Chomsky stated that the language acquisition device is an innate language device that is owned by children who can acquire a language, which embodies rules of "universal grammar". It means that the child is born with an innate knowledge of or the predisposition toward language and that this innate property (LAD) is universal in all human beings (Brown 1994). In the case of Genie, due to being isolated and minimal contact with other people until the age of 14 years, she was unable to acquire the grammatical rules of English. She couldn't speak good grammatical structure, had a lack of auxiliary verbs, and lacked the past tense marker, the third person singular agreement marker, and most pronouns. But, after being trained, she could utter some words. So, it means that as a human being, her innate language device exists. Pinker (cited in Carlson, 1997) maintained that an innate language acquisition device guides the child's acquisition of a language, which is part of a general theory about the cognitive structures responsible for language and its acquisition. The most important components are as follows: 
a. Children learning a language make hypotheses about the grammatical rules they require following. These hypotheses are corroborated or not by the speech that they hear.

b. An innate language acquisition device (a part of the brain) guides children's hypotheses formation. Due to possessing this device, there are certain types of hypothetical rules that they will never entertain and certain types of sentences that they will never utter.

c. The language acquisition device (LAD) makes reinforcement unnecessary; the device motivates for the child to learn a language.

d. Learning a language has a critical period. The LAD works best during childhood; languages are difficult to learn and almost impossible to master.

\section{Imitation}

Since the researcher quite often uses English to communicate with Addien, she imitates some words that I taught to her such as teaching her numbers in English. One of the examples of imitation done by her is as one of the ways the child uses in language acquisition, as children are "good imitators". Even though the imitation does not work well and cannot say that it gives a great impact on the child's language development, in fact, in the earlier stages, it can be applied and gives a contribution to her vocabulary. Brown (1994, 2000) divided imitation into two types: surface-structured imitation, where a person repeats or mimics the surface strings, attending to a phonological code rather than a semantic code. It is this level of imitation that enables an adult to repeat random numbers or nonsense syllables, or even to mimic unknown languages. The data of semantic, if any, underlying the surface 
output are neither internalized nor attended to internalize. In the classes of foreign language, rote pattern drills often evoke surface imitation: a repetition of sounds by a student without the vaguest understanding of what the sounds might mean. At the earliest stages of child language acquisition, they are likely to exhibit a good deal of surface imitation since the baby might not have the required semantic categories to assign "meaning" to utterances. Nonetheless, as children perceive the importance of the semantic level of language, they attend primarily if not exclusively to that significant level- the deep structure of language as a second type of imitation. They participate in deep-structure imitation. In fact, the deep structure imitation can block their attention to the surface structure so as they become poor imitators.

This imitation, as a part of the habit - formation theory of the structural linguists, plays as a significant role as repetition in its approach. Repeated occurrences of the response form a constant pattern. The child is reinforced for the correct response again after he imitates the adults he hears. This language acquisition theory is based on the view that language is acquired behavior resulting from habits. Such habits are formed by practice and repetition (Boey, 1975). This theory is similar to a behavioristic model of first language acquisition would claim that practice-repetition and association- is the key to the habit formation by operant conditioning proposed by Skinner (Brown 1994). Brown (2000) also believed that language learning is the result of imitation, practice, feedback on success, and habit formation. In line with practice, Goldstein (1984) shows that corrected practices enhance language learning. 


\section{Environment and immediate family}

Conducive and positive environment, as well as interaction from immediate family and media, contributes to the process of language development, as language acquisition is a creative process. Her ability to communicate is developed stunningly after the age of three years because of the mentioned factors above. The stimulation of the environment affects language ability. Ambridge, et al. (2015) and Reali and Christiansen (2007) pointed out "the most-immediate environmental effect on language pertains to the frequency of language use, which affects both acquisition and adult language processing." AlHammadi (2017) also found that child language development is not only affected by environmental, but also by social and genetic factors. It revealed that the social class, family history, environmental, and genetic factors contribute to the prediction of child's language development. Foley and Thompson (2003) and Moon (2000) acknowledged that correspondingly children in EFL settings are likely to enhance their learning as long as they live in a "community" where people actively speak English.

Chomsky (1965) highlighted "Basically, language learning is not something that the child does, it is something that happens to the child placed in the proper environment, much as the child's body grows and matures in a predetermined way when appropriate nutrition and environmental stimulation are provided for the child". Since she was a baby, she has already had exposure to people in her surroundings. Her mother puts a lot of pictures to stimulate her understanding and vocabulary. In the hierarchy of learning proposed by Robert M. Gagne that the first stage of learning is a concrete concept, which means 
the children must see the things or objects (use five senses). By showing and exposing a lot of pictures, it can help a child to know, understand, and utter the words that contribute not only to his/her language acquisition but also to her psycho motoric aspect. The researcher buys a lot of VCDs or DVDs so that she, at least, is familiar with English since early childhood. When I bought her a movie Barbie VCD of "Barbie \& her sisters in a Pony tale" and watched it several times, she knew a concept of horse and that horse is a tame animal that she can ride on it. Beforehand, she was afraid of a horse, when I took her to Pacuan Kuda and asked her to ride a horse. She also has plenty of words from all of us ( 8 adult people) who communicate and have interaction with her. She learns a lot from those things: environment, significant others (immediate family) and media that support, and affect her linguistic ability. Hoff (2003) emphasized that children's surrounding and social interaction with the family member and the community affect their language acquisition as well.

Last but not least, in addition to mentioned factors, according to Ball (2010), some factors affecting the outcomes of dual language acquisition include formal instruction, individual differences, socio cultural adaptation, language spoken (exposure) at home, motivation, ethnic/gender discrimination, physiological condition and family socio economic status.

\section{CONCLUSION}

Dual language learning is not confusing as some common beliefs or myths occur to some parents. On the other hand, the children benefit some advantages such as they are better at problem solving, demonstrate greater creativity and express more tolerant attitudes. There are also some benefits the children can obtain from learning a second/foreign language, especially if the 
language is learned in the early childhood since the articulation of children is still developed until the age of 12 years old. They can also understand their mother tongue better as in the case of Chinese's children. They can recognize whether the word is their mother's first language or not. Therefore, the younger the individual is exposed to a new language, the greater the probability of acquiring native pronunciation as well as proficiency in that language.

To promote the child's acquisition, the role of significant others - that is immediate family; parents, grandparents, sisters, or brother is essential either to stimulate a child's brain or to affect their language development. The conducive and favorable environment also has a profound impact on children's acquisition, that's why, parents must provide positive environments such as selecting good program television programs, having interaction with peers to improve not only linguistics ability but also communication skills and psychomotor of a child. Thus, it can be concluded that factors affecting children acquisition include linguistic input or exposure, which will support and develop their linguistic ability; language acquisition device that motivate the children to learn; imitation, which such habits are formed by practice and repetition; environment and immediate family.

The result of this research might be different if it is applied to other children due to factors such as environment, social status, intelligence, exposure and genetic. There are also some differences between children who acquire the same language since each child is different about the process of acquiring the languages. Accordingly, the individual differences (ID) must be taken into a consideration, as there is a significant variation among speakers at 
any ages as well as across the lifespan. Therefore, future research about individual differences (ID) needs to be addressed to analyze further potential variables.

\section{REFERENCES}

AlHammadi, F.S (2017). Prediction of child language development: A review of literature in early childhood communication disorders. Lingua Volume 199, Pp. 27-35.

Ambridge, B., Kidd, E., Rowland C.F., \& Theakston, A.L. (2015). The ubiquity of frequency effects in first language acquisition. Journal of Child Language. 42, 239-273. Doi: 10.1017/S030500091400049X

Ball, J. (2011). Enhancing learning of children from diverse language backgrounds: Mother tongue -based bilingual or multilingual education in early years. Paris: UNESCO

Bialystok, E., \& Martin, M. (2004). Attention and inhibition in bilingual children: Evidence from The dimensional change card sort task. Developmental Science, 7, 325-339

Boey, L.K. (1975). An Introduction to linguistics for the language teacher. Monograph Series. SEAMEO Singapore: Singapore University Press

Brown, H.D. (1994). Principles of language learning and teaching. New Jersey: Prentice Hall Regent

Brown, H. D. (2000). Principles of language learning \& teaching. (4th ed.). New York: Longman.

Brown, H. D. (2007). Principles of language learning and teaching. (5th ed). New York: Pearson Education.

Brown, R. (1973). A first language: the early stages. Cambridge, MA: Harvard University Press. 
Carlson, N.R. \& Buskist, W. (1997). Psychology: The science of behavior. USA: Allyn and Bacon

Chomsky, N. (1965). Aspects of theory of syntax. Cambridge, MA: MIT Press.

Cummins, J. (1981). The role of primary language development in promoting educational success for language minority students. In California State Department of Education (Ed.), Schooling and language Assessment Center.

Dye, C., Kedar, Y., \& Lust, B. (2018). From lexical to functional categories: New foundations for the study of language development. First Language, 39(1), 9-32. Doi:10.1177/0142723718809175

Ellis, R. (1994) The study of second language acquisition. Oxford: Oxford University Press.

Espinosa, L. M. (2008). Challenging common myths about young English language learners. Foundation for Child Development Policy Brief 8. Retrieved from http://fcdus.org/resources/challenging-common-myths-aboutyoung-english-language-learners

Ferjan Ramirez, N., Ramírez, R. R., Clarke, M., Taulu, S., \& Kuhl, P. K. (2016). Speech discrimination in 11-month-old bilingual and monolingual infants: a magnetoencephalography study. Developmental Science, 20(1), e12427. doi:10.1111/desc.12427

Fletcher, P. (1985). A child's learning of English. Oxford: Basil Blackwell.

Foley, J., \& Thompson, L. (2003). Language learning: A lifelong process. London: Arnold.

Fromkin, V., Robert R \& Hyams, N. (2003). An Introduction to Language. USA: Thomson Wadsworth

Genesee, F. (2008). Early Dual Language Learning. Zero to three Training Institute conference. Retrieved from http// www.zerotothree.org. 
Genesee, F., \& Gandara, P. (1999). Bilingual education programs: A crossnational perspective. Journal of Social Issues, $55,665-685$.

Genesee, F., Boivin, I., \& Nicoladis, E. (1996). Talking with strangers: A study of bilingual children's communicative competence. Applied Psycholinguistics, $17,427-442$.

Goldstein, H. (1984). Effects of modeling and corrected practice in generative language learning of preschool children. Journal of Speech and Hearing Disorders, 49, pp.389-398. Doi :10.1044/jshd.4904.389

Green, M., \& Piel, J. (2016). Theories of human development: A comparative approach (2nd ed.). New York: Routledge

Halliday, M.A.K. (1975). Learning how to mean. London: Edward Arnold.

Harry, B. (1992). Developing cultural self-awareness: The first step in values clarification for early interventionists. Topics in Early Childhood Special Education, 12(3), 333-350

Hartshorne, J.K., Tenenbauma, J.B., Pinker, S. (2018). A critical period for second language acquisition: Evidence from 2/3 million English speakers. Cognition. https://doi.org/10.1016/j.cognition.2018.04.007

Heidar, D. M. (2012). First language acquisition: Psychological considerations and epistemology. Theory and Practice in Language Studies, 2(2), pp. 411416. doi:10.4304/tpls.2.2.411-416

Hyltenstam, K., \& Abrahamsson, N. (2003). Maturational constraints in SLA. In

C. J. Doughty \& M. Long (Eds.), The handbook of second language acquisition (pp. 539-588). Malden, MA: Blackwell.

Hirsh-Pasek, K. et al. (2015) The contribution of early communication quality to low-income children's language success. Psychological Science. 26, 10711083

Hoff, E. (2001). Language development. Belmont: Thompson Learning, Inc. 
Hoff, E. (2003). The specificity of environmental influence: Socioeconomic status affect early vocabulary development via maternal speech. Child Development. 74, 1368-1378

Hoff, E. et al. (2012), Dual language exposure and early bilingual development, Journal of Child Language, 39/01,1-27, http://dx.doi.org/10.1017/S0305000910000759.

Johnson, M. (2004). A Philosophy of second language acquisition. New Haven: Yale University Press.

Krashen, S. D. (1995). Principles and practice in second language acquisition. Hemel Hempstead, Hertfordshire: Prentice Hall Europe.

Krashen, S. (2003). Explorations in language acquisition and use: The Taipei Lectures. Portsmouth, NH: Heinemann.

Kuhl, P. (2011), "Early language learning and literacy: Neuroscience implications for education", Mind, Brain and Education, 5/3,128-142, http://dx.doi.org/10.1111/j.1751-228X.2011.01121.x.

Lee, J.S \& Jeong, E. (2013). Korean-English dual language immersion: perspectives of students, parents and teachers. Language, Culture and Curriculum, 26:1, 89-107, DOI: 10.1080/07908318.2013.765890

Lenneberg, E.H. (1967). Biological foundations of language. New York: John Wiley \& Sons.

Lightbown, P. \& Spada, N. (2006). How languages are learned (3rd edition). Oxford:

Oxford University Press.

Lightbown, P. (2008). Easy as pie? Children learning languages. Concordia Working Papers in Applied Linguistics, 1, 1-25. 
Lin, C.Y., Cheng, C. \& Wang, M. (2018). The contribution of phonological and morphological awareness in Chinese-English bilingual reading acquisition. Reading and Writing: An Interdisciplinary Journal, Volume 31, No.1 pp.99-132. https://doi.org/10.1007/s11145-017-9775-8

Miles, M. B., Huberman, A. M., \& Saldana. J. (2014). Qualitative Data Analysis: A Sourcebook. Thousand Oaks, Calif: Sage

Moon, J. (2000). Children learning English. Oxford: Macmillan Publishers Ltd.

Mushi, S. (2002) Acquisition of multiple languages among children of immigrant families: Parents' role in the home-school language pendulum, Early Child Development and Care, 172:5, 517530, DOI: $\underline{10.1080 / 03004430214546}$

Nordquist, R. (April 14, 2018). Language acquisition in children: Glossary of Grammatical and Rhetorical Terms. Retrieved from https://www.thoughtco.com/what-is-language-acquisition-1691213

Orillos, L. Q. (1998). Language acquisition theories, principles, and research. Quezon City: UPOU.

Pernille, H. (2016). What makes a word easy to acquire? The Effects of word class, frequency, imageability and phonological neighbourhood density on lexical development. First Language, 37 (2), 205-225 doi:10.1177/0142723716679956

Pinker, S. (1995). Language Acquisition. Retrieved from http://users.ecs.ac.uk/harnad/papers

Reali, F. \& Christiansen, M.H. (2007) Processing of relative clauses is made easier by frequency of occurrence. Journal of Memory and Language 57 (2007) 1-23

Rowe, M. (2012). A longitudinal exploration of the role of quantity and quality of child-directed speech in vocabulary development. Child Development. 83, 1762-1774 
Rowe, M. et al. (2016). Going beyond input quantity: Wh-questions matter for toddlers' language and cognitive development. Cognitive Science. 41, 162-179

Shuttleworth, M. (2008). Case study research design. Retrieved from https://explorable.com/case-study-research-design

Tahriri, A. (2013). Revisiting first language acquisition through empirical and rational perspectives. International Journal of Social Science \& Education, 3(3), 677-682.

Tong, X; McBride, C; Ho, C.S; Waye, M.M.Y.; Chung, K.KH; Wong, S.W.L; Chow, B. W.Y. (2018). Within and Cross-Language Contributions of Morphological Awareness to Word Reading and Vocabulary in ChineseEnglish Bilingual Learners. Reading and Writing: An Interdisciplinary Journal, vol. 31 no. 8 pp. 1765-1786. https://doi.org/10.1007/s11145-0179771-z

Weisleder, A. \& Fernald, A. (2013). Talking to children matters: early language experience strengthens processing and builds vocabulary. Psychological Science. 24, 2143-2152

Wray, A \& Bloomer, A. (2006). Project in linguistics: practical guide to researching language. London: Hodder Education.

Yin, R. K. (2003). Case study research: Design and methods. (3rd edition). California: Sage

Publication, Inc. 